\title{
Natural History, Clinical Manifestations, and Pathogenesis of Hepatitis A
}

\author{
Eui-Cheol Shin ${ }^{1}$ and Sook-Hyang Jeong ${ }^{2}$ \\ ${ }^{1}$ Laboratory of Immunology and Infectious Diseases, Graduate School of Medical Science and Engineering, \\ KAIST, Daejeon 34141, Republic of Korea \\ ${ }^{2}$ Department of Internal Medicine, Seoul National University Bundang Hospital, College of Medicine, Seoul \\ National University, Seongnam, Gyeonggido 13620, Republic of Korea \\ Correspondence: jsh@snubh.org
}

\begin{abstract}
Hepatitis A virus (HAV) is transmitted by the fecal-oral route and is a major cause of acute viral hepatitis. The clinical manifestations of HAV infection range from asymptomatic infection to acute liver failure (ALF), but do not include progression to chronic hepatitis. Risk factors for severe acute hepatitis $\mathrm{A}$ are older age ( $>40$ years) and preexisting liver disease. Some patients may show atypical clinical features such as relapsing hepatitis, prolonged cholestasis, or extrahepatic manifestations. Almost all hepatitis A patients spontaneously recover with supportive care. However, in the case of $\operatorname{ALF}(<1 \%)$, intensive care and urgent decision on liver transplantation are required. Liver injury during hepatitis $\mathrm{A}$ is not directly caused by HAV but is known to be caused by immune-mediated mechanisms. In this review, the natural history and clinical manifestations of hepatitis A are described. In addition, mechanisms of immunopathogenesis in hepatitis A are discussed.
\end{abstract}

$\mathrm{H}$ epatitis A virus (HAV) is transmitted by the fecal-oral route and is a major cause of acute viral hepatitis, which can lead to acute liver failure (ALF) and mortality in severe cases. The number of global hepatitis A cases was $\sim 1.4$ million with 27,731 deaths in 2010 (Havelaar et al. 2015). HAV infection often causes symptomatic hepatitis in adults, whereas it tends to result in an asymptomatic subclinical infection in children. Following socioeconomic development and public health improvement, the global incidence of HAV infection has been decreasing. However, an increasing number of individuals are infected at older ages, leading to more severe clinical manifestations and greater disease bur- den (Murphy et al. 2016). The clinical manifestations of HAV infection range from asymptomatic infection to ALF, and some patients show atypical features such as relapsing hepatitis or prolonged cholestatic hepatitis, as well as extrahepatic manifestations. In this review, we consider pitfalls in the diagnosis of hepatitis A, therapeutic considerations including predictors for urgent liver transplantation, and mechanisms of pathogenesis.

\section{NATURAL HISTORY OF HEPATITIS A}

HAV is highly stable in ambient temperatures and can withstand low $\mathrm{pH}$, drying, and deter-

Editors: Stanley M. Lemon and Christopher Walker

Additional Perspectives on Enteric Hepatitis Viruses available at www.perspectivesinmedicine.org

Copyright (C) 2018 Cold Spring Harbor Laboratory Press; all rights reserved; doi: 10.1101/cshperspect.a031708

Cite this article as Cold Spring Harb Perspect Med 2018;8:a031708 


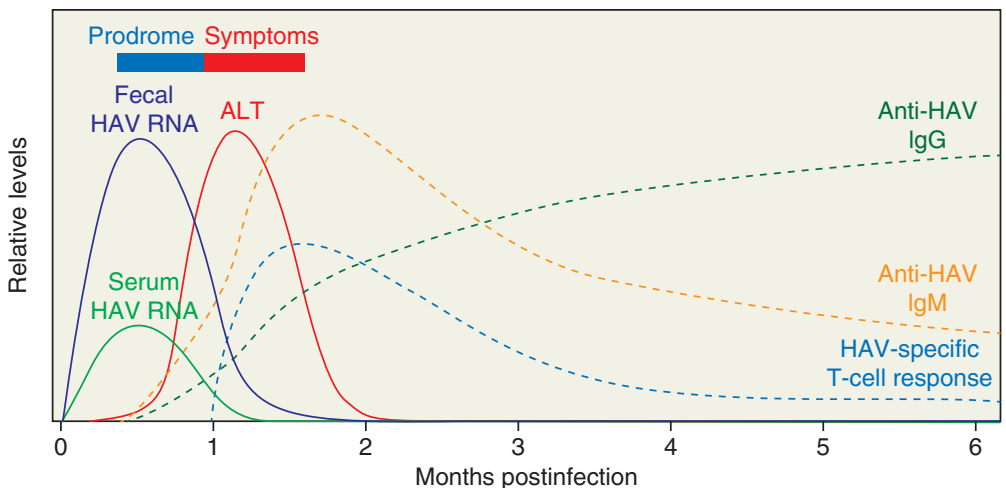

Figure 1. A typical course of hepatitis A. After a 3- to 5-week incubation period following hepatitis A virus (HAV) infection, patients develop symptoms of hepatitis with elevation of serum alanine aminotransferase (ALT) levels. Fecal virus shedding and viremia are present and peak during the incubation period. Anti-HAV antibodies appear in serum first as immunoglobulin (Ig)M and subsequently as IgG. Virus-specific T-cell responses coincide with the elevation of serum ALT levels.

gents. HAV inactivation requires heating foods $\left(>85^{\circ} \mathrm{C}\right)$ for 1 min or disinfecting surfaces with a 1:100 dilution of sodium hypochlorite (household bleach) for 1 min (Nainan et al. 2006). After ingestion of HAV through the fecal-oral route, HAV survives the acidic stomach environment and is ultimately delivered to the liver. Whether it first replicates at a primary site within the gastrointestinal tract is uncertain. HAV replicates in hepatocytes and is then secreted into bile and thus back into the gastrointestinal tract. It is finally excreted via feces or transferred to the liver through an enterohepatic cycle until virus neutralization (Cuthbert 2001).

Following an incubation period of 15-50 days (mean, 30 days) after HAV infection, patients develop symptoms of acute hepatitis with elevated levels of serum aspartate/alanine aminotransferases (AST/ALTs) (Fig. 1). Before symptoms, there are waves of viremia and copious amounts of fecal viral shedding. Feces are the primary source of HAV transmission because of their high viral load. In comparison, serum HAV concentrations are two or three $\log _{10}$ units lower than in the feces (Martin and Lemon 2006). Therefore, risk of transmission is highest during the prodromal phase before symptoms or biochemical manifestations. The virus is also shed in the saliva at even lower concentrations (Amado Leon et al. 2015). Con- cordant with clinical hepatitis, anti-HAV immunoglobulin $\mathrm{M}(\mathrm{Ig}) \mathrm{M}$ and subsequently antiHAV IgG appear in the serum and saliva, accompanied by a marked reduction of fecal virus shedding and viremia (Fig. 1). Although antiHAV IgM is detectable for up to 6 months, antiHAV IgG persists, conferring lifelong immunity (Normann et al. 2004).

\section{CLINICAL MANIFESTATIONS OF HEPATITIS A}

\section{Clinical Signs and Symptoms of Acute Hepatitis A}

The clinical manifestations of HAV infection range from asymptomatic infection to ALF, but it does not progress to chronic hepatitis. Development of symptomatic hepatitis is associated with patient age. Relatively few children under 6 years of age $(<30 \%)$ manifest hepatitis symptoms, whereas the majority of adults ( $>70 \%$ ) develop symptoms that persist for 2-8 weeks (Fig. 2) (Armstrong and Bell 2002). The onset of hepatitis A is often abrupt with fever $(18 \%-75 \%)$, malaise $(52 \%-91 \%)$, nausea or vomiting (26\%-87\%), abdominal discomfort $(37 \%-65 \%)$, and then dark urine $(28 \%-94 \%)$ and jaundice. Less commonly, pruritus, diarrhea, arthralgia, or skin rash develop. When 


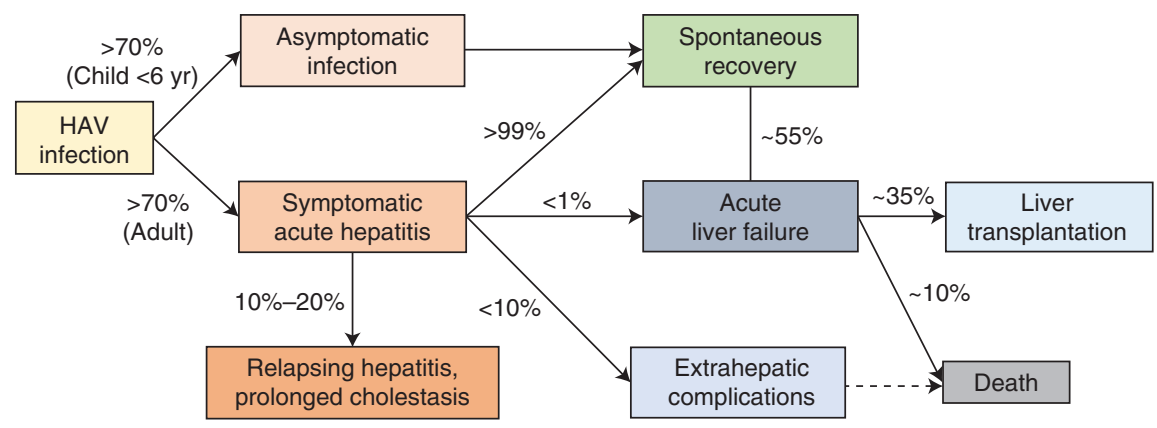

Figure 2. The clinical outcomes of hepatitis A virus (HAV) infection. Clinical manifestations of HAV infection depend on the age of patients. Most adult patients develop symptomatic hepatitis, whereas most young children do not. Common hepatitis symptoms are fever, malaise, nausea or vomiting, abdominal discomfort, and dark urine and jaundice. Reported extrahepatic complications include acute kidney injury, acalculous cholecystitis, pancreatitis, pleural or pericardial effusion, hemolysis, hemophagocytosis, pure red-cell aplasia, acute reactive arthritis, skin rash, and neurological manifestations such as mononeuritis, Guillain-Barré syndrome, and transverse myelitis.

the patient seeks medical advice, the fever has usually disappeared. On physical examination, hepatomegaly $(78 \%)$ and jaundice $(40 \%-80 \%)$ are frequently detected (Koff 1992; Khan et al. 2012).

\section{Laboratory Findings and Diagnosis}

Laboratory results show elevated levels of total bilirubin (mean peak level of $7-13 \mathrm{mg} / \mathrm{dL}$ ), alkaline phosphatase (mean peak level of 319$335 \mathrm{IU} / \mathrm{L}$ ), and ALT (mean peak level of 1952$3628 \mathrm{IU} / \mathrm{L})$. Sometimes, very high levels of ALT $(\sim 10,000 \mathrm{IU} / \mathrm{L})$ are observed, but this is not a poor prognostic indicator (Tong et al. 1995; Jung et al. 2010b). Prolonged prothrombin time ([PT] $<40 \%$ ) and high bilirubin levels in the absence of hemolysis indicate severe hepatitis with a potential risk for ALF. Radiological findings of hepatitis A include hepatomegaly, gallbladder wall thickening more than $3 \mathrm{~mm}$ (80\%) with arterial heterogeneity, periportal tracking, and perihepatic lymph node enlargement $(>7 \mathrm{~mm}$ in diameter) (Fig. 3) (Park et al. 2013). Gallbladder wall thickening is associated with high bilirubin levels and may be an independent factor of severe hepatitis, which is defined as $\mathrm{PT} \leq 40 \%$ or bilirubin $\geq 10 \mathrm{mg} / \mathrm{dL}$ (Suk et al. 2009).

Because symptoms or biochemical laboratory findings are nonspecific for HAV infection, serological confirmation is essential for diagnosis. Detection of serum anti-HAV IgM via commercially available assays is the primary diagnostic method in clinical settings. However, $6 \%-11 \%$ of symptomatic patients do not show a detectable anti-HAV IgM at clinical onset, especially during the early symptomatic phase (Jung et al. 2010b; Lee et al. 2013). Therefore, repeated examination of anti-HAV IgM 2 to 5 days after the first examination should be performed if there is clinical suspicion. Seroconversion to anti-HAV IgM positivity on the second examination leads to the correct hepatitis A diagnosis. Rarely (8\%-20\%), anti-HAV IgM can be transiently detected in persons who have recently received an HAV vaccine (Nainan et al. 2006). Previous HAV infection is diagnosed by a positive serum anti-HAV test in the absence of IgM anti-HAV. Although saliva anti-HAV IgM testing can be used as a screening test in the setting of outbreak investigations, its sensitivity is lower than serum testing (Amado Leon et al. 2015).

\section{Complications of Acute Hepatitis A}

HAV infection is self-limited and does not progress to chronic hepatitis. However, $10 \%-20 \%$ of patients develop relapsing hepatitis or prolonged cholestasis lasting for more than 6 
E.-C. Shin and S.-H. Jeong
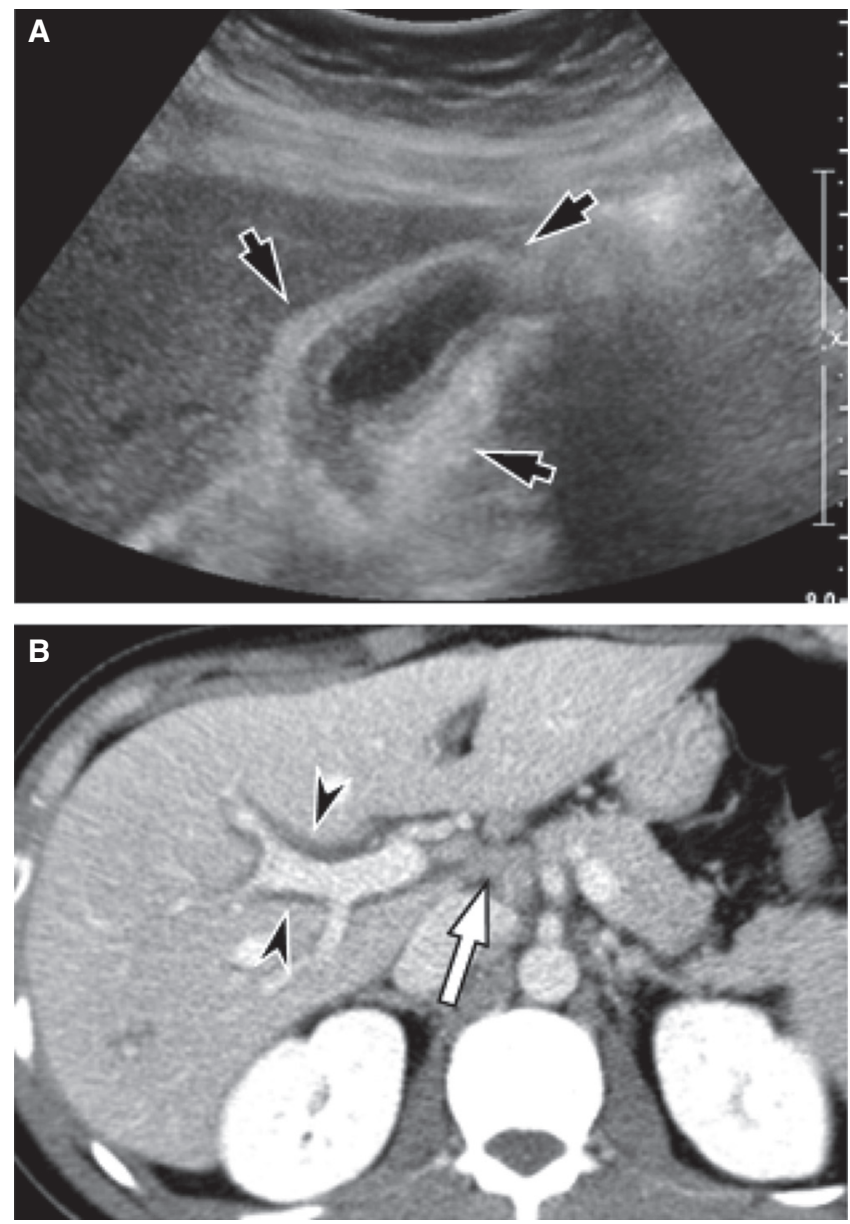

Figure 3. Radiological findings of hepatitis A. (A) Transabdominal ultrasonography shows diffuse wall thickening of the gallbladder (arrows) measuring $\sim 10 \mathrm{~mm}$. (B) Transverse computed tomography (CT) scan depicts low attenuating halo around the right portal vein indicating periportal tracking (arrowheads). Perihepatic lymph node enlargement is also noted (arrow).

months (Fig. 2). Relapsing hepatitis develops in up to $12 \%$ of patients after initial hepatitis resolution but is mostly a milder form of hepatitis compared with the initial one. Viremia and fecal viral shedding reappear with relapsing hepatitis (Glikson et al. 1992). A study using a chimpanzee model suggested that relapsing hepatitis might be associated with rapid contraction of or failure to maintain virus-specific $\mathrm{CD} 4^{+} \mathrm{T}$ cell responses (Zhou et al. 2012).

Prolonged cholestasis (total bilirubin level $>5 \mathrm{mg} / \mathrm{dL}$ lasting for $>4$ weeks) is observed in $5 \%-7 \%$ of patients and presents with pruritus and fatigue. It is related to preexisting chronic hepatitis B, prolonged PT, and high total bilirubin at initial examination (Jung et al. 2010b). Although these patients show severe cholestasis with total bilirubin levels of up to $40 \mathrm{mg} / \mathrm{dL}$, patients are generally in good condition with nearly normal levels of AST/ALT and PT and finally recover.

\section{Acute Liver Failure in the Setting of HAV Infection}

Hepatitis A severity is related to age at infection and preexisting liver diseases. ALF, which develops in $0.015 \%-0.5 \%$ of hepatitis A patients, has 
the highest rates in older adults $(>40-50$ years of age) and patients with underlying chronic liver diseases with limited hepatic functional reserve (Chen et al. 2016; Murphy et al. 2016). In a prospective, multicenter study in South Korea of 595 adult hepatitis A cases (mean age of 31 years), $99.5 \%$ of patients spontaneously recovered, $0.5 \%$ developed ALF, and $0.2 \%$ experienced ALF-related mortality (Jung et al. 2010b). The 1988 Shanghai hepatitis A epidemic, which affected $>300,000$ people mostly in their 20 s to $40 \mathrm{~s}$, showed a similar case fatality rate $(0.015 \%)$. In that study, the case fatality rate of hepatitis A with underlying chronic hepatitis B $(0.05 \%)$ was 5.6 times higher than in those without hepatitis B virus infection (0.009\%) (Keeffe 1995; Cooksley 2000).

The effect of HAV viral load on the ALF risk is controversial. One study reported that lower serum HAV viral load was associated with a higher risk of ALF (Rezende et al. 2003). However, more recent studies have shown that a higher viral load is related to ALF (Lee et al. 2015). Variable blood sampling times and the fluctuating nature of viremia during the acute phase may be related to this discrepancy. Likewise, although nucleotide sequence variation in the $5^{\prime}$ nontranslated segment of the HAV genome has been associated with severe acute hepatitis $\mathrm{A}$, this has not been confirmed (Fujiwara et al. 2002; Kanda et al. 2010; Ajmera et al. 2011). A human genetic polymorphism, 157insMTTTVP, in the gene encoding T-cell immunoglobulin and mucin domain-1 (TIM1)/HAVCR1 was associated with ALF in Argentinean patients (Kim et al. 2011). TIM1 is a phosphatidylserine receptor that facilitates cellular entry of many enveloped viruses. Recent studies show that it does not play an essential role in HAV entry, but TIM1 does enhance uptake of quasi-enveloped "eHAV" virions (Das et al. 2017).

HAV-related ALF outcomes from a U.S. study $(n=29)$ and a South Korean study $(n=$ 35) similarly showed that $55 \%-57 \%$ of patients spontaneously recovered, $31-38 \%$ underwent liver transplantation, and 6\%-14\% died without transplantation (Fig. 2). A prognostic model incorporating serum ALT $<2600 \mathrm{IU} / \mathrm{L}$, creatinine $>2.0 \mathrm{mg} / \mathrm{dL}$, intubation, and pressor use was proposed for predicting transplantation or death (Taylor et al. 2006). An independent factor for spontaneous survival was degree of hepatic encephalopathy in the Korean study (Kim et al. 2008).

\section{Extrahepatic Manifestations}

Reported extrahepatic manifestations include acute kidney injury, acalculous cholecystitis, pancreatitis, pleural or pericardial effusion, hemolysis, hemophagocytosis, pure red-cell aplasia, acute reactive arthritis, skin rash, and neurological manifestations such as mononeuritis, Guillain-Barré syndrome, and transverse myelitis (Jeong and Lee 2010). Acute kidney injury (AKI), defined by serum creatinine level $>2.0$ $\mathrm{mg} / \mathrm{dL}$ or at least a 1.5 -fold increase from baseline serum creatinine level, develops in $1.5 \%$ $7.6 \%$ of hepatitis A patients (Jung et al. 2010b; Choi et al. 2011). Prerenal azotemia, interstitial nephritis, and acute tubular necrosis predominantly contribute to AKI in hepatitis A along with intravascular hemolysis, direct hepatotoxicity of hyperbilirubinemia, or immune complex-associated glomerulopathy. It is associated with older age ( $>40$ years), male sex, diabetes, high alcohol intake, leukocytosis, elevated $\mathrm{C}$ reactive protein (CRP) level, higher bilirubin level, higher AST/ALT level, or low albumin level. In nonfulminant hepatitis A, $10 \%-50 \%$ of AKI cases require renal replacement therapy (Jung et al. 2010a). Rare cases of autoimmune hepatitis following hepatitis A have been reported. However, prior HAV infection has been associated with a lower probability of having hay fever and asthma (Matricardi et al. 2002).

Hepatitis A during pregnancy is generally benign. However, preterm uterine contraction is commonly associated with HAV infection, especially during the second and third trimester. This may be associated with proinflammatory cytokines or hyperbilirubinemia. In Israel, 13 pregnant cases showed a high rate $(9 / 13,69 \%)$ of gestational complications such as premature contraction, placental separation, premature rupture of membranes, and vaginal bleeding (Elinav et al. 2006). In 12 South Korean pregnancy cases, there were two preterm labors, one 
premature rupture of membranes, and one fetal ascites and intraabdominal calcification, which spontaneously resolved (Cho et al. 2013). Fetal meconium peritonitis may be related to intrauterine HAV infection, which in two reported cases led to neonatal small bowel perforation (Leikin et al. 1996; McDuffie and Bader 1999). However, fetal outcome is generally benign and mother-to-child transmission is very rare. Although HAV RNA may be detected in breast milk, breastfeeding is not contraindicated.

\section{Management}

There is no specific antiviral therapy for hepatitis A. Supportive care such as adequate hydration and symptomatic control of fever or vomiting with antipyretics or antiemetics is generally performed. Extrahepatic complications must be monitored, and renal function support via hemodialysis may be required. In the case of prolonged cholestasis, a few studies have reported response to corticosteroid therapy. However, corticosteroid treatment should be used with caution, considering the prolonged presence of HAV RNA (up to 12 months) in the liver (Lanford et al. 2011) and potentially harmful effects of corticosteroids on the immune control of HAV. Administration of ursodeoxycholic acid or cholestyramine may be considered for pruritus control (Jeong and Lee 2010). Furthermore, hepatitis A-associated ALF may rapidly progress within a week. Thus, intensive, multidisciplinary care and recognition of poor prognostic factors are needed to facilitate urgent decision-making situations regarding liver transplantation.

\section{PATHOGENESIS}

\section{Viral Replication in the Host}

According to a recent study, a quasi-enveloped form of HAV (eHAV) is detected in the serum and plasma of infected hosts, whereas a nonenveloped, naked form of HAV is shed through feces (Fig. 4) (Feng et al. 2013). eHAV is released from hepatocytes and subsequently loses its lipid envelope following exposure to high concen- trations of bile salts in the biliary canaliculus (Walker et al. 2015; Hirai-Yuki et al. 2016b). HAV can take advantage of the specific characteristics of eHAV and nonenveloped HAV for immune evasion and efficient viral transmission, respectively. Within infected hosts, the quasi-envelope of eHAV cloaks the capsid, sequestering it from neutralizing antibodies that target capsid proteins (Feng et al. 2013). Nonenveloped, naked HAV is very stable and is shed in feces via the intestinal tract while preserving its infectivity. Moreover, in the environment, nonenveloped, naked HAV is highly transmissible to other hosts because of its high physicochemical stability (Walker et al. 2015).

During acute hepatitis A, peaks of fecal shedding of the virus and viremia are followed by hepatocellular injury, which is manifested by elevation of liver enzymes in the serum such as ALT (Fig. 1) (Shin et al. 2016a). After the first increase in serum ALT levels, viral shedding in feces usually continues for $\sim 2$ to 3 weeks, although sensitive reverse transcription polymerase chain reaction methods may detect it for longer periods (Martin and Lemon 2006). Clinical relapse with fecal viral shedding can occur following the resolution of hepatitis A (Sjogren et al. 1987), and prolonged viremia has also been reported in some adult patients with hepatitis A (Normann et al. 2004). A chimpanzee study reported the persistence of hepatitis $C$ virus (HCV) RNA in the liver for months after cessation of fecal virus excretion (Lanford et al. 2011). Meanwhile, protracted forms of HAV infection were strongly associated with a specific HLA-DR allele, HLA-DRB1*1301 (Fainboim et al. 2001).

Extrahepatic sites of HAV replication have been suggested. In fact, HAV antigens can be detected in not only hepatocytes but also in the spleen, lymph nodes, and kidneys of infected nonhuman primates (Mathiesen et al. 1978). HAV antigens have also been detected in small intestine crypt cells in owl monkeys (Aotus trivirgatus) orally inoculated with HAV (Asher et al. 1995); this has not been confirmed in humans. In addition, HAV has been detected in the tonsils and saliva shortly after viremia (Cohen et al. 1989) although the viral titer in saliva is very low. 


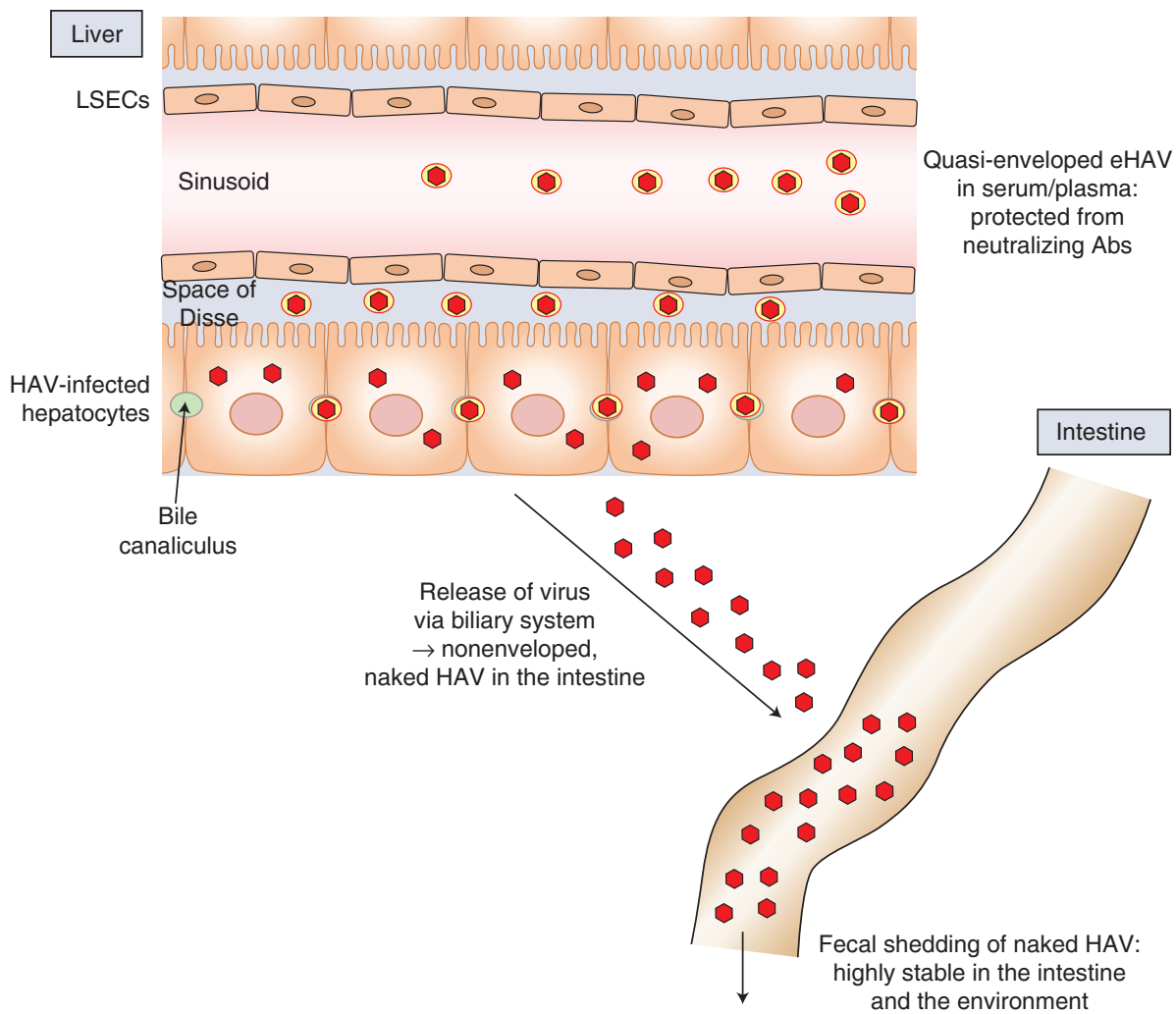

Figure 4. Two different forms of infectious hepatitis A virus (HAV) virions. Quasi-enveloped HAV (eHAV) is detected in serum and plasma of the infected host, whereas nonenveloped, naked HAV is shed in feces. New replicated progeny virus is released from hepatocytes in the quasi-enveloped form and subsequently loses its lipid envelope following exposure to bile salts in the biliary canaliculus. The viral capsid within the quasi-enveloped eHAV virion is protected from neutralizing antibodies. Nonenveloped, naked HAV is highly stable. It is shed in feces via the intestinal tract and maintains infectivity in the environment. LSECs, Liver sinusoidal endothelial cells.

\section{Liver Injury}

As described above, acute HAV infection often causes severe liver injury in adults, whereas it tends to result in a subclinical, asymptomatic infection in children (Shin et al. 2016a). ALF develops in extreme cases. In the liver with hepatitis $\mathrm{A}$, hepatocyte degeneration and infiltration by mononuclear inflammatory cells are observed. Activation of Kupffer cells and disruption of bile canaliculi may also be observed.

The mechanism for liver injury during hepatitis A has not yet been clearly elucidated. Moreover, the reason why adults tend to experience symptomatic liver injury after HAV infection is poorly understood. However, it is known that the liver injury is not caused by direct cytopathic effect of HAV (Siegl and Weitz 1993). This is indirectly supported by the fact that viral replication and fecal excretion both peak before serum ALT level elevation. Moreover, HAV-infected cells do not show cytopathic effects, and their metabolism is not impacted when infected by HAV in vitro (Gauss-Muller and Deinhardt 1984), further indicating that hepatitis A liver injury is not caused by virusinduced cytopathology. Instead, liver injury in hepatitis A is caused by immune-mediated mechanisms involving both innate and adaptive immune responses to the virus (Shin et al. 2016a). Indeed, patient studies indicate possible roles for T cells, cytokines, and chemokines in liver injury during hepatitis $\mathrm{A}$, as described below. 
E.-C. Shin and S.-H. Jeong

\section{MECHANISMS OF IMMUNOPATHOGENESIS}

\section{T Cells}

During hepatitis A, the appearance of T cells in the liver temporally coincides with an increase in serum ALT levels (Fig. 1), suggesting an important role for $\mathrm{T}$ cells in liver injury (Shin et al. 2016a). At the same time, viral titers in feces and serum start to decrease. Virus-specific $\mathrm{CD}^{+} \mathrm{T}$ cells may contribute to both viral control and liver injury in HAV-infected hosts. Early studies reported that peripheral blood lymphocytes or liver-derived $\mathrm{CD}^{+} \mathrm{T}$-cell clones from hepatitis A patients exert cytotoxicity against HAV-infected cells (Kurane et al. 1985; Vallbracht et al. 1986, 1989) and produce IFN- $\gamma$ (Kurane et al. 1985; Maier et al. 1988; Fleischer et al. 1990), which can amplify inflammation at the infection site. Following on these early reports, other studies suggest a role for HAV-specific $\mathrm{CD}^{+} \mathrm{T}$ cells in the induction of liver injury in hepatitis A. A recent study described $\mathrm{CD}^{+} \mathrm{T}$ cell responses targeting multiple epitopes of HAV and observed an activated phenotype of $\mathrm{HAV}$-specific $\mathrm{CD}^{+} \mathrm{T}$ cells in the blood of patients with acute HAV infection (Schulte et al. 2011). On the contrary, a chimpanzee study showed that $\mathrm{HAV}$-specific $\mathrm{CD}^{+} \mathrm{T}$ cells were undetectable in the blood during acute HAV infection or were nonfunctional if detected (Zhou et al. 2012). Instead, $\mathrm{HAV}$-specific $\mathrm{CD}^{+} \mathrm{T}$ cells were detected and polyfunctional. In summary, how T cells contribute to liver injury in hepatitis A has yet to be fully elucidated, including antigen specificity, subsets, activating signals, and effector molecules, all of which need to be further clarified.

A role for natural killer T (NKT) cells was suggested in relation to the 157insMTTTVP polymorphism described above in the gene encoding TIM-1/HAVCR1 (Kim et al. 2011). TIM1 was previously considered to be an essential cellular receptor for HAV, but is now known to contribute only to the cellular entry of quasienveloped virions (Das et al. 2017). Severe HAVinduced liver injury was associated with the six amino acid insertion in TIM-1 (Kim et al. 2011). Moreover, NKT cells expressing the long form of TIM-1 exerted stronger cytolytic activity against HAV-infected cells than those expressing the short form (Kim et al. 2011).

\section{Antibodies and Immune Complexes}

Early clinical studies showed immune complex deposition in the liver and reduced levels of serum complement in hepatitis A patients (Inman et al. 1986; Margolis et al. 1988). These immune complexes contained IgM and IgG antibodies, HAV capsid proteins, and C3 complement cleavage products (Margolis et al. 1988). However, it is not clear whether immune complexes and complement activation contribute to liver inflammation and injury during hepatitis A.

A recent study with peripheral blood from hepatitis A patients showed that a substantial number of antibody-secreting cells (ASCs) have specificities to antigens unrelated to $\mathrm{HAV}$, a bone marrow plasma cell-like phenotype, and dominantly secrete IgM during acute HAV infection (Hong et al. 2013). These data suggest that preexisting plasma cells are mobilized and released into the circulation and contribute to antigennonspecific IgM secretion during acute HAV infection. However, the role of the antigen-nonspecific IgM response in the immunopathogenesis of HAV infection has not yet been clarified.

\section{Cytokines and Chemokines}

Diverse cytokines and chemokines play a role in immune-mediated host injury by their effector and immunomodulatory functions. In hepatitis A patients, serum levels of several cytokines and chemokines are increased compared with healthy controls, including interleukin (IL)-6, IL-8, IL-18, IL-22, CXC-chemokine ligand (CXCL)9, and CXCL10, although the cells that produce them have not been identified (Shin et al. 2016b). In addition, serum levels of granzyme B and soluble Fas ligand, which are molecules involved in T-cell cytotoxicity, are also increased in hepatitis A patients. Among them, serum levels of Fas ligand and IL-18 significantly correlate with serum ALT levels and total bilirubin levels, respectively, in hepatitis A patients (Shin et al. 2016b), suggesting that differ- 
ent immune mechanisms may contribute to hepatocellular injury and cholestatic injury during hepatitis A. Moreover, serum levels of CXCL9 and CXCL10 significantly correlate with serum ALT levels (Shin et al. 2016b). CXCL9 and CXCL10 are chemokines that recruit effector T cells to peripheral inflammatory sites by binding to CXCR3, which is typically expressed by effector helper $1 \mathrm{CD}^{+}{ }^{+} \mathrm{T}$ cells and cytotoxic $\mathrm{CD}^{+} \mathrm{T}$ cells. Amplification of liver injury by antigennonspecific mononuclear cells, which are recruited to the liver by CXCL9 and CXCL10, is well known, although studied in a murine model of hepatitis B (Iannacone et al. 2007).

Very recently, a unique mechanism for CXCL10 production in $\mathrm{HAV}$-infected cells was elucidated. HAV RNA is sensed by pathogen-associated molecular pattern receptors such as MDA5 in the cytosol or TLR3 in the endosome (Fig. 5). However, downstream signals are interrupted by HAV proteins. An intermediate product of HAV polyprotein processing, 3ABC, cleaves MAVS (Yang et al. 2007), and another precursor, 3CD, cleaves TRIF (Qu et al. 2011). In addition, the HAV $3 \mathrm{C}^{\text {pro }}$ protease cleaves NEMO (Wang et al. 2014). Although HAV blocks signals downstream from MDA5 and TLR3 by such mechanisms, type III interferon (IFN)- $\lambda s$ and CXCL10 are produced by HAV-infected cells, particularly at an early stage of HAV infection (Sung et al. 2017). CXCL10 is produced in HAV-infected cells in a MAVS and IRF3-dependent manner (Fig. 5) (Sung et al. 2017). However, secreted type I or III IFNs are not required for CXCL10 production. This finding corresponds to the fact that CXCL10 expression is increased in the liver and blood of $\mathrm{HAV}$-infected chimpanzees, whereas IFN responses are minimally induced in the infected liver (Lanford et al. 2011). This mechanism may be pivotal for liver inflammation during HAV infection, as it induces the production of CXCL10 even without IFNs. Similar findings have been reported in a murine model of hepatitis A (see below) (Hirai-Yuki et al. 2016a).

\section{Regulatory T Cells}

In immune-mediated host injury, regulatory $\mathrm{T}$ (Treg) cells can modulate effector T-cell activity.
Treg cells have been shown to play a role in liver injury regulation during acute $\mathrm{HAV}$ infections. The number of circulating $\mathrm{CD} 4{ }^{+} \mathrm{CD} 25^{+} \mathrm{Foxp} 3^{+}$ Treg cells is diminished by Fas-mediated apoptosis during hepatitis A (Choi et al. 2015). In addition, the suppressive function of Treg cells can be directly inhibited by the binding of HAV particles to TIM-1 expressed by Treg cells (Manangeeswaran et al. 2012). Furthermore, the number of Treg cells in the blood and the suppressive activity of the total Treg cell population are inversely correlated with serum ALT levels (Choi et al. 2015). These data indicate that decreased $\mathrm{CD} 4^{+} \mathrm{CD} 25^{+}$Foxp $3^{+}$Treg cell population activity is associated with severe liver injury during hepatitis A. However, the frequency of circulating Treg cells does not correlate with the frequency of $\mathrm{HAV}$-specific, IFN- $\boldsymbol{\gamma}$-producing $\mathrm{CD}^{+} \mathrm{T}$ cells in the blood (Choi et al. 2015). Further studies are required to identify the effector cells mainly targeted by the suppressive activity of Treg cells during hepatitis A and to clarify how reduced Treg cell population frequencies and activities are related to liver injury.

\section{A Murine Model of HAV Infection}

As described above, the mechanisms responsible for immune-mediated liver injury have not yet been clearly elucidated. This is in part attributed to the absence of a small animal model for HAV infection and hepatitis A. Recently, a murine model of HAV infection with human hepatitis A features was described (Hirai-Yuki et al. 2016a). In this study, mice lacking the type I IFN receptor or both type I and II IFN receptors were inoculated intravenously with $\mathrm{HAV}$, resulting in the development of features typifying human hepatitis A, including fecal virus shedding, viremia, increased serum ALT levels, necrosis or apoptosis of hepatocytes, and infiltration of the liver by inflammatory cells, including macrophages, natural killer cells, and $\mathrm{CD}^{+}$and $\mathrm{CD}^{+}$T cells (Hirai-Yuki et al. 2016a). Further analyses with this model revealed that hepatocellular apoptosis and hepatic inflammation occurs by a MAVS and IRF3/7-dependent, but IFN-independent mechanism (Hirai-Yuki et al. 2016a). In this model, multiple cytokines 
E.-C. Shin and S.-H. Jeong
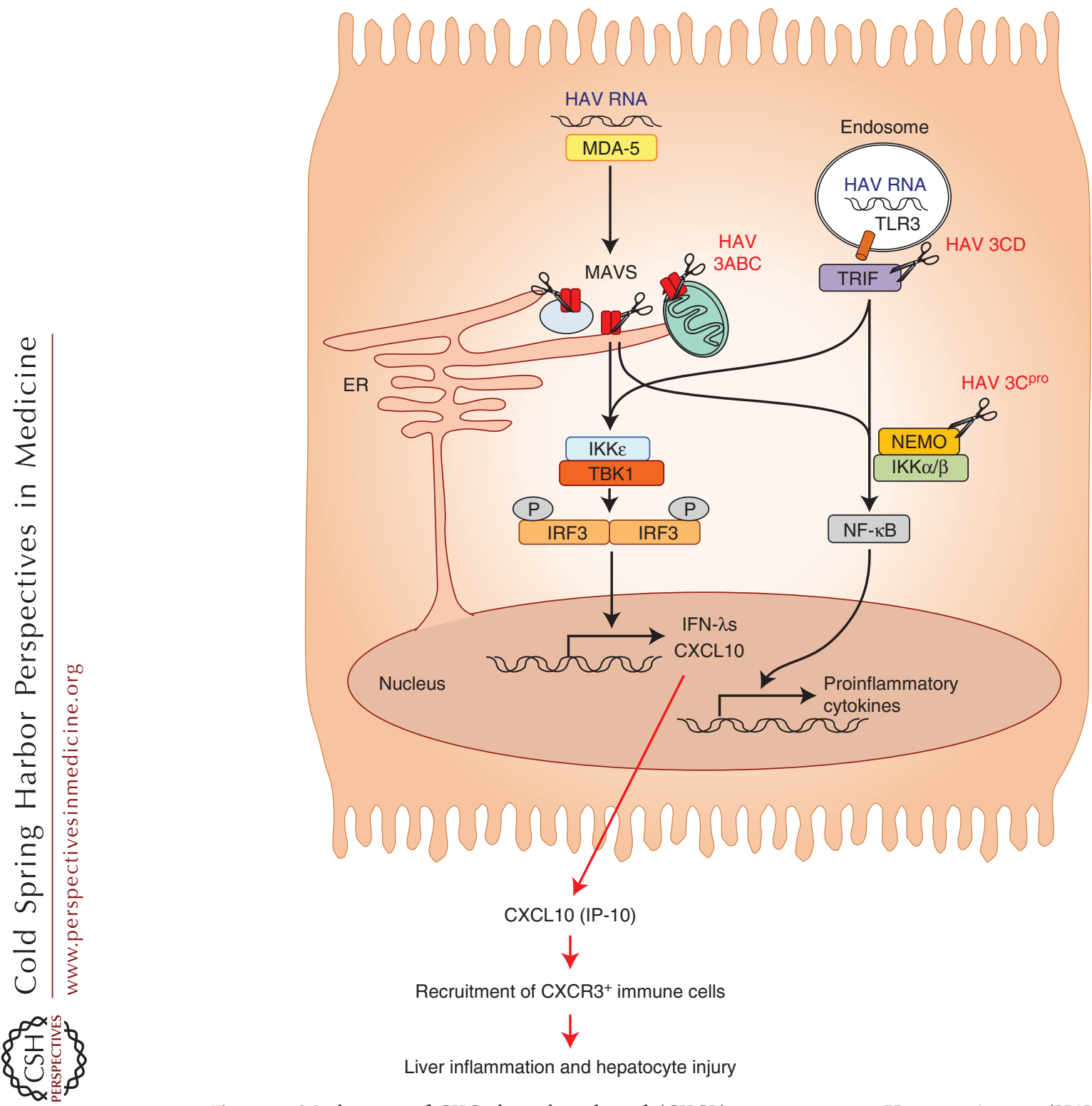

Figure 5. Mechanism of CXC-chemokine ligand (CXCL)10 expression in Hepatitis A virus (HAV)-infected hepatocytes. HAV RNA is sensed by MDA5 in the cytosol or TLR3 in the endosome. However, downstream signaling is interrupted by HAV proteins as described in the text. Nonetheless, interferon $\lambda$ (IFN- $\lambda$ ) and CXCL10 are produced from HAV-infected cells, particularly at an early stage of HAV infection. CXCL10 is produced in HAVinfected cells in a MAVS- and IRF3-dependent but IFN-independent manner. CXCL10 can contribute to liver inflammation and hepatocyte injury by recruiting CXCR ${ }^{+}$immune cells to the HAV-infected liver.

and chemokines were expressed in the liver by the same mechanism (Hirai-Yuki et al. 2016a), corresponding with the recent finding in human cells described above (Sung et al. 2017). This study revealed the critical role of MAVS signal- ing in liver injury induced by HAV infection using a unique murine model. However, it remains to be confirmed whether this model exactly recapitulates the mechanisms of pathogenesis of hepatitis A in humans. 


\section{CONCLUDING REMARKS}

In regions with inadequate levels of sanitation, $\mathrm{HAV}$ is readily propagated among children and often results in a self-limited, asymptomatic, and subclinical infection, which induces neutralizing antibodies that confer lifelong protective immunity. Thus, improvements in sanitation increase the size of the HAV-naïve adult population susceptible to HAV infection. In this situation, increasing numbers of individuals can be infected at older ages, leading to more severe clinical manifestations and greater disease burden. Currently, inactivated HAV vaccines that elicit neutralizing antibodies are available, and vaccination will largely reduce the incidence of HAV infection and symptomatic hepatitis.

Although liver injury in hepatitis A is known to be caused by immune-mediated events, the exact pathogenesis mechanisms have not yet been clarified. Immune-mediated mechanisms of liver injury are common to the pathogenesis of hepatitis A, hepatitis B, and hepatitis C (Shin et al. 2016a). Elucidating the immunopathogenesis of hepatitis A will not only lead to better clinical management of hepatitis A patients, but could also facilitate the development of novel therapeutic approaches reducing liver injury in patients with hepatitis B or C.

\section{ACKNOWLEDGMENTS}

We are grateful to Dr. Yoon Jin Lee in the Department of Radiology in Seoul National University Bundang Hospital for selecting and describing the radiological images of our patients. We also thank Prof. Su-Hyung Park (Graduate School of Medical Science and Engineering, KAIST) and Dr. Hyung-Don Kim (Graduate School of Medical Science and Engineering, KAIST) for critical reading of the manuscript. This work is supported by the $\mathrm{Na}$ tional Research Foundation Grant NRF2014R1A2A1A10053662, and the Korea Advanced Institute of Science and Technology Future Systems Healthcare Project, which is funded by the Ministry of Science, ICT, and Future Planning of Korea.

\section{REFERENCES}

Ajmera V, Xia G, Vaughan G, Forbi JC, Ganova-Raeva LM, Khudyakov Y, Opio CK, Taylor R, Restrepo R, Munoz S, et al. 2011. What factors determine the severity of hepatitis A-related acute liver failure? J Viral Hepat 18: e167-e174.

Amado Leon LA, de Almeida AJ, de Paula VS, Tourinho RS, Villela DA, Gaspar AM, Lewis-Ximenez LL, Pinto MA. 2015. Longitudinal study of hepatitis A infection by saliva sampling: The kinetics of HAV markers in saliva revealed the application of saliva tests for hepatitis A study. PLoS ONE 10: e0145454.

Armstrong GL, Bell BP. 2002. Hepatitis A virus infections in the United States: Model-based estimates and implications for childhood immunization. Pediatrics 109: 839845.

Asher LV, Binn LN, Mensing TL, Marchwicki RH, Vassell RA, Young GD. 1995. Pathogenesis of hepatitis A in orally inoculated owl monkeys (Aotus trivirgatus). J Med Virol 47: 260-268.

Chen CM, Chen SC, Yang HY, Yang ST, Wang CM. 2016. Hospitalization and mortality due to hepatitis A in Taiwan: A 15-year nationwide cohort study. J Viral Hepat 23: 940-945.

Cho GJ, Kim YB, Kim SM, Hong HR, Kim JH, Seol HJ, Hong SC, Oh MJ, Kim HJ. 2013. Hepatitis A virus infection during pregnancy in Korea: Hepatitis A infection on pregnant women. Obstet Gynecol Sci 56: 368-374.

Choi HK, Song YG, Han SH, Ku NS, Jeong SJ, Baek JH, Kim H, Kim SB, Kim CO, Kim JM, et al. 2011. Clinical features and outcomes of acute kidney injury among patients with acute hepatitis A. J Clin Virol 52: 192-197.

Choi YS, Lee J, Lee HW, Chang DY, Sung PS, Jung MK, Park JY, Kim JK, Lee JI, Park H, et al. 2015. Liver injury in acute hepatitis A is associated with decreased frequency of regulatory T cells caused by Fas-mediated apoptosis. Gut 64: 1303-1313.

Cohen JI, Feinstone S, Purcell RH. 1989. Hepatitis A virus infection in a chimpanzee: Duration of viremia and detection of virus in saliva and throat swabs. J Infect Dis 160: 887-890.

Cooksley WG. 2000. What did we learn from the Shanghai hepatitis A epidemic? J Viral Hepat 7: 1-3.

Cuthbert JA. 2001. Hepatitis A: Old and new. Clin Microbiol Rev 14: 38-58.

Das A, Hirai-Yuki A, González-López O, Rhein B, MollerTank S, Brouillette R, Hensley L, Misumi I, Lovell W, Cullen JM, et al. 2017. TIM1 (HAVCR1) is not essential for cellular entry of either quasi-enveloped or naked hepatitis A virions. mBio 8: e00969-00917.

Elinav E, Ben-Dov IZ, Shapira Y, Daudi N, Adler R, Shouval D, Ackerman Z. 2006. Acute hepatitis A infection in pregnancy is associated with high rates of gestational complications and preterm labor. Gastroenterology 130: 11291134.

Fainboim L, Canero Velasco MC, Marcos CY, Ciocca M, Roy A, Theiler G, Capucchio M, Nuncifora S, Sala L, Zelazko M. 2001. Protracted, but not acute, hepatitis A virus infection is strongly associated with HLA$\mathrm{DRB}^{*} 1301$, a marker for pediatric autoimmune hepatitis. Hepatology 33: 1512-1517. 
Feng Z, Hensley L, McKnight KL, Hu F, Madden V, Ping L, Jeong SH, Walker C, Lanford RE, Lemon SM. 2013. A pathogenic picornavirus acquires an envelope by hijacking cellular membranes. Nature 496: 367-371.

Fleischer B, Fleischer S, Maier K, Wiedmann KH, Sacher M, Thaler H, Vallbracht A. 1990. Clonal analysis of infiltrating $\mathrm{T}$ lymphocytes in liver tissue in viral hepatitis $\mathrm{A}$. Immunology 69: 14-19.

Fujiwara K, Yokosuka O, Ehata T, Saisho H, Saotome N, Suzuki K, Okita K, Kiyosawa K, Omata M. 2002. Association between severity of type $A$ hepatitis and nucleotide variations in the $5^{\prime}$ non-translated region of hepatitis $\mathrm{A}$ virus RNA: Strains from fulminant hepatitis have fewer nucleotide substitutions. Gut 51: 82-88.

Gauss-Muller V, Deinhardt F. 1984. Effect of hepatitis A virus infection on cell metabolism in vitro. Proc Soc Exp Biol Med 175: 10-15.

Glikson M, Galun E, Oren R, Tur-Kaspa R, Shouval D. 1992. Relapsing hepatitis A. Review of 14 cases and literature survey. Medicine 71: 14-23.

Havelaar AH, Kirk MD, Torgerson PR, Gibb HJ, Hald T, Lake RJ, Praet N, Bellinger DC, de Silva NR, Gargouri $\mathrm{N}$, et al. 2015. World Health Organization global estimates and regional comparisons of the burden of foodborne disease in 2010. PLoS Med 12: e1001923.

Hirai-Yuki A, Hensley L, McGivern DR, Gonzalez-Lopez O, Das A, Feng H, Sun L, Wilson JE, Hu F, Feng Z, et al. 2016a. MAVS-dependent host species range and pathogenicity of human hepatitis A virus. Science 353: 15411545.

Hirai-Yuki A, Hensley L, Whitmire JK, Lemon SM. 2016b. Biliary secretion of quasi-enveloped human hepatitis A virus. mBio 7: e01998-01916.

Hong S, Lee HW, Chang DY, You S, Kim J, Park JY, Ahn SH, Yong D, Han KH, Yoo OJ, et al. 2013. Antibody-secreting cells with a phenotype of Ki- $67^{\text {low }}, \mathrm{CD} 138^{\text {high }}, \mathrm{CD} 31^{\text {high }}$, and $\mathrm{CD} 38^{\text {high }}$ secrete nonspecific IgM during primary hepatitis A virus infection. J Immunol 191: 127-134.

Iannacone M, Sitia G, Ruggeri ZM, Guidotti LG. 2007. HBV pathogenesis in animal models: Recent advances on the role of platelets. J Hepatol 46: 719-726.

Inman $\mathrm{RD}$, Hodge $\mathrm{M}$, Johnston ME, Wright J, Heathcote J. 1986. Arthritis, vasculitis, and cryoglobulinemia associated with relapsing hepatitis A virus infection. Ann Intern Med 105: 700-703.

Jeong SH, Lee HS. 2010. Hepatitis A: Clinical manifestations and management. Intervirology 53: 15-19.

Jung YJ, Kim W, Jeong JB, Kim BG, Lee KL, Oh KH, Yoon JH, Lee HS, Kim YJ. 2010a. Clinical features of acute renal failure associated with hepatitis A virus infection. J Viral Hepat 17: 611-617.

Jung YM, Park SJ, Kim JS, Jang JH, Lee SH, Kim JW, Park YM, Hwang SG, Rim KS, Kang SK, et al. 2010b. Atypical manifestations of hepatitis A infection: A prospective, multicenter study in Korea. J Med Virol 82: 1318-1326.

Kanda T, Jeong SH, Imazeki F, Fujiwara K, Yokosuka O. 2010. Analysis of $5^{\prime}$ nontranslated region of hepatitis A viral RNA genotype I from South Korea: Comparison with disease severities. PLoS ONE 5: e15139.
Keeffe EB. 1995. Is hepatitis A more severe in patients with chronic hepatitis $\mathrm{B}$ and other chronic liver diseases? Am J Gastroenterol 90: 201-205.

Khan KM, Kumar NC, Gruessner RW. 2012. The liver and parenteral nutrition. In Zakim and Boyer's hepatology: A textbook of liver disease, 6th ed. (ed. Boyer TD, Manns MP, Sanyal AJ), pp. 986-995. W.B. Saunders, Philadelphia.

Kim JM, Lee YS, Lee JH, Kim W, Lim KS. 2008. Clinical outcomes and predictive factors of spontaneous survival in patients with fulminant hepatitis A. Korean J Hepatol 14: 474-482.

Kim HY, Eyheramonho MB, Pichavant M, Gonzalez Cambaceres C, Matangkasombut P, Cervio G, Kuperman S, Moreiro R, Konduru K, Manangeeswaran M, et al. 2011. A polymorphism in TIM1 is associated with susceptibility to severe hepatitis A virus infection in humans. J Clin Invest 121: 1111-1118.

Koff RS. 1992. Clinical manifestations and diagnosis of hepatitis A virus infection. Vaccine 10: S15-S17.

Kurane I, Binn LN, Bancroft WH, Ennis FA. 1985. Human lymphocyte responses to hepatitis A virus-infected cells: Interferon production and lysis of infected cells. J Immunol 135: 2140-2144.

Lanford RE, Feng Z, Chavez D, Guerra B, Brasky KM, Zhou Y, Yamane D, Perelson AS, Walker CM, Lemon SM. 2011. Acute hepatitis A virus infection is associated with a limited type I interferon response and persistence of intrahepatic viral RNA. Proc Natl Acad Sci 108: 11223-11228.

Lee HK, Kim KA, Lee JS, Kim NH, Bae WK, Song TJ. 2013. Window period of anti-hepatitis A virus immunoglobulin $\mathrm{M}$ antibodies in diagnosing acute hepatitis A. Eur J Gastroenterol Hepatol 25: 665-668.

Lee HW, Chang DY, Moon HJ, Chang HY, Shin EC, Lee JS, Kim KA, Kim HJ. 2015. Clinical factors and viral load influencing severity of acute hepatitis A. PLoS ONE 10: e0130728.

Leikin E, Lysikiewicz A, Garry D, Tejani N. 1996. Intrauterine transmission of hepatitis A virus. Obstet Gynecol 88: 690-691.

Maier K, Gabriel P, Koscielniak E, Stierhof YD, Wiedmann KH, Flehmig B, Vallbracht A. 1988. Human $\gamma$ interferon production by cytotoxic $\mathrm{T}$ lymphocytes sensitized during hepatitis A virus infection. J Virol 62: 3756-3763.

Manangeeswaran M, Jacques J, Tami C, Konduru K, Amharref N, Perrella O, Casasnovas JM, Umetsu DT, Dekruyff RH, Freeman GJ, et al. 2012. Binding of hepatitis A virus to its cellular receptor 1 inhibits T-regulatory cell functions in humans. Gastroenterology 142: 1516-1525. e1513.

Margolis HS, Nainan OV, Krawczynski K, Bradley DW, Ebert JW, Spelbring J, Fields HA, Maynard JE. 1988. Appearance of immune complexes during experimental hepatitis A infection in chimpanzees. J Med Virol 26: 315-326.

Martin A, Lemon SM. 2006. Hepatitis A virus: From discovery to vaccines. Hepatology 43: S164-S172.

Mathiesen LR, Drucker J, Lorenz D, Wagner JA, Gerety RJ, Purcell RH. 1978. Localization of hepatitis A antigen in marmoset organs during acute infection with hepatitis A virus. J Infect Dis 138: 369-377. 
Matricardi PM, Rosmini F, Panetta V, Ferrigno L, Bonini S 2002. Hay fever and asthma in relation to markers of infection in the United States. J Allergy Clin Immunol 110: 381-387.

McDuffie RS Jr, Bader T. 1999. Fetal meconium peritonitis after maternal hepatitis A. Am J Obstet Gynecol 180: 1031-1032.

Murphy TV, Denniston MM, Hill HA, McDonald M, Klevens MR, Elam-Evans LD, Nelson NP, Iskander J, Ward JD. 2016. Progress toward eliminating hepatitis A disease in the United States. MMWR Suppl 65: 29-41.

Nainan OV, Xia G, Vaughan G, Margolis HS. 2006. Diagnosis of hepatitis A virus infection: A molecular approach. Clin Microbiol Rev 19: 63-79.

Normann A, Jung C, Vallbracht A, Flehmig B. 2004. Time course of hepatitis A viremia and viral load in the blood of human hepatitis A patients. J Med Virol 72: 10-16.

Park SJ, Kim JD, Seo YS, Park BJ, Kim MJ, Um SH, Kim CH, Yim HJ, Baik SK, Jung JY, et al. 2013. Computed tomography findings for predicting severe acute hepatitis with prolonged cholestasis. World J Gastroenterol 19: 2543 2549.

Qu L, Feng Z, Yamane D, Liang Y, Lanford RE, Li K, Lemon SM. 2011. Disruption of TLR3 signaling due to cleavage of TRIF by the hepatitis A virus protease-polymerase processing intermediate, 3CD. PLoS Pathog 7: e1002169.

Rezende G, Roque-Afonso AM, Samuel D, Gigou M, Nicand E, Ferre V, Dussaix E, Bismuth H, Feray C. 2003. Viral and clinical factors associated with the fulminant course of hepatitis A infection. Hepatology 38: 613-618.

Schulte I, Hitziger T, Giugliano S, Timm J, Gold H, Heinemann FM, Khudyakov Y, Strasser M, Konig C, Castermans E, et al. 2011. Characterization of $\mathrm{CD}^{+} \mathrm{T}$-cell response in acute and resolved hepatitis A virus infection. $J$ Hepatol 54: 201-208.

Shin EC, Sung PS, Park SH. 2016a. Immune responses and immunopathology in acute and chronic viral hepatitis. Nat Rev Immunol 16: 509-523.

Shin SY, Jeong SH, Sung PS, Lee J, Kim HJ, Lee HW, Shin EC. 2016b. Comparative analysis of liver injury-associated cytokines in acute hepatitis A and B. Yonsei Med J 57: 652657.
Siegl G, Weitz M. 1993. Pathogenesis of hepatitis A: Persistent viral infection as basis of an acute disease? Microb Pathog 14: 1-8.

Sjogren MH, Tanno H, Fay O, Sileoni S, Cohen BD, Burke DS, Feighny RJ. 1987. Hepatitis A virus in stool during clinical relapse. Ann Intern Med 106: 221-226.

Suk KT, Kim CH, Baik SK, Kim MY, Park DH, Kim KH, Kim JW, Kim HS, Kwon SO, Lee DK, et al. 2009. Gallbladder wall thickening in patients with acute hepatitis. J Clin Ultrasound 37: 144-148.

Sung PS, Hong SH, Lee J, Park SH, Yoon SK, Chung WJ, Shin EC. 2017. CXCL10 is produced in hepatitis A virusinfected cells in an IRF3-dependent but IFN-independent manner. Sci Rep 7: 6387.

Taylor RM, Davern T, Munoz S, Han SH, McGuire B, Larson AM, Hynan L, Lee WM, Fontana RJ. 2006. Fulminant hepatitis A virus infection in the United States: Incidence, prognosis, and outcomes. Hepatology 44: 1589-1597.

Tong MJ, el-Farra NS, Grew MI. 1995. Clinical manifestations of hepatitis A: Recent experience in a community teaching hospital. J Infect Dis 171: S15-S18.

Vallbracht A, Gabriel P, Maier K, Hartmann F, Steinhardt HJ, Muller C, Wolf A, Manncke KH, Flehmig B. 1986. Cell-mediated cytotoxicity in hepatitis A virus infection. Hepatology 6: 1308-1314.

Vallbracht A, Maier K, Stierhof YD, Wiedmann KH, Flehmig B, Fleischer B. 1989. Liver-derived cytotoxic T cells in hepatitis A virus infection. J Infect Dis 160: 209-217.

Walker CM, Feng Z, Lemon SM. 2015. Reassessing immune control of hepatitis A virus. Curr Opin Virol 11: 7-13.

Wang D, Fang L, Wei D, Zhang H, Luo R, Chen H, Li K, Xiao S. 2014. Hepatitis A virus 3C protease cleaves NEMO to impair induction of $\beta$ interferon. J Virol 88: 10252-10258.

Yang Y, Liang Y, Qu L, Chen Z, Yi M, Li K, Lemon SM. 2007. Disruption of innate immunity due to mitochondrial targeting of a picornaviral protease precursor. Proc Natl Acad Sci 104: 7253-7258.

Zhou Y, Callendret B, Xu D, Brasky KM, Feng Z, Hensley LL Guedj J, Perelson AS, Lemon SM, Lanford RE, et al. 2012. Dominance of the $\mathrm{CD}^{+} \mathrm{T}$ helper cell response during acute resolving hepatitis A virus infection. J Exp Med 209: 1481-1492. 


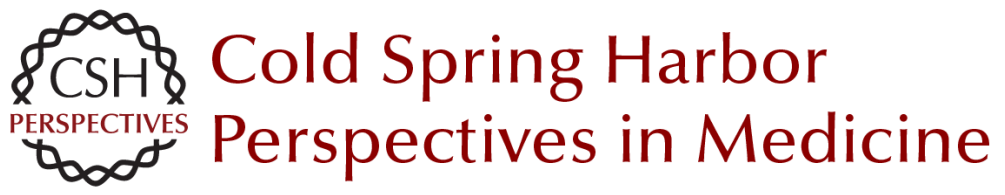

\section{Natural History, Clinical Manifestations, and Pathogenesis of Hepatitis A}

Eui-Cheol Shin and Sook-Hyang Jeong

Cold Spring Harb Perspect Med 2018; doi: 10.1101/cshperspect.a031708 originally published online February 12, 2018

Subject Collection Enteric Hepatitis Viruses

Hepatitis A Virus Genome Organization and

Replication Strategy

Kevin L. McKnight and Stanley M. Lemon

Adaptive Immune Responses in Hepatitis A Virus

and Hepatitis E Virus Infections

Christopher M. Walker

Small Animal Models of Hepatitis E Virus Infection

Tian-Cheng Li and Takaji Wakita

Acute and Persistent Hepatitis E Virus Genotype 3 and 4 Infection: Clinical Features, Pathogenesis, and Treatment

Nassim Kamar and Sven Pischke

Epidemiology of Genotype 1 and 2 Hepatitis E

Virus Infections

Kenrad E. Nelson, Alain B. Labrique and Brittany L. Kmush

History of the Discovery of Hepatitis A Virus Stephen M. Feinstone

Epidemiology and Transmission of Hepatitis A Virus and Hepatitis E Virus Infections in the United States

Megan G. Hofmeister, Monique A. Foster and Eyasu $\mathrm{H}$. Teshale

Stem Cell-Derived Culture Models of Hepatitis E

Virus Infection

Viet Loan Dao Thi, Xianfang Wu and Charles $M$.

Rice

Evolutionary Origins of Enteric Hepatitis Viruses

Anna-Lena Sander, Victor Max Corman, Alexander N. Lukashev, et al.

Enterically Transmitted Non-A, Non-B Hepatitis and the Discovery of Hepatitis E Virus

Stanley M. Lemon and Christopher M. Walker

Natural History, Clinical Manifestations, and

Pathogenesis of Hepatitis E Virus Genotype 1 and

2 Infections

Rakesh Aggarwal and Amit Goel

Hepatitis A Virus and Hepatitis E Virus: Emerging and Re-Emerging Enterically Transmitted

Hepatitis Viruses

Stanley M. Lemon and Christopher M. Walker

Hepatitis A Virus Capsid Structure

David I. Stuart, Jingshan Ren, Xiangxi Wang, et al.

Comparative Pathology of Hepatitis A Virus and

Hepatitis E Virus Infection John M. Cullen and Stanley M. Lemon

Innate Immunity to Enteric Hepatitis Viruses Zongdi Feng and Stanley M. Lemon

Nonhuman Primate Models of Hepatitis A Virus and Hepatitis E Virus Infections

Robert E. Lanford, Christopher M. Walker and

Stanley M. Lemon

For additional articles in this collection, see http://perspectivesinmedicine.cshlp.org/cgi/collection/ 